\title{
The Fresnel Affair: Manufacturing, Technology Transfer, Republicanism, and the Adoption of the Fresnel Lighthouse Lens in the United States, 1819 - 1852
}

\section{James Risk}

\begin{abstract}
Les historiens croient que le United States Lighthouse Establishment a tardé à adopter la lentille révolutionnaire inventée par l'ingénieur civil français Augustin Fresnel. Le présent article conteste cette interprétation en examinant la lentille de Fresnel dans le contexte de la diffusion des connaissances et du transfert de technologie au début du 19e siècle. L'auteur affirme que l'adoption de la lentille de phare de Fresnel par les États-Unis était tout à fait comparable à celle d'autres pays et au même niveau que le taux de diffusion des connaissances attendu dans le monde maritime du début des années 1800.
\end{abstract}

On 23 February 1843, Secretary of the Treasury Walter Forward wrote to the Honorable John White, Speaker for the House of Representatives, responding to public criticisms of the Treasury's management of the United States Light-House Establishment. In his letter, Secretary Forward argued, "it has been impossible to guard against all abuses. These necessarily result from the existing defects in the system and must not be readily imputed to mismanagement of the Department." Historians of the Light-House Establishment, however, have failed to acknowledge the secretary's comments or the system under which the Treasury managed the nation's coastal beacons. Several historians have called out the Treasury Department for its mismanagement of the Light-House Establishment citing a

1 Walter Forward to John White, 23 February 1843, in United States Congress, Examination Light-House Establishment, $27^{\text {th }}$ Cong., $3^{\text {rd }}$ sess., H. Doc. 183 (1843), 3.

The Northern Mariner / Le marin du nord, XVIII, No. 4 (Autumn 2018), 363-84 


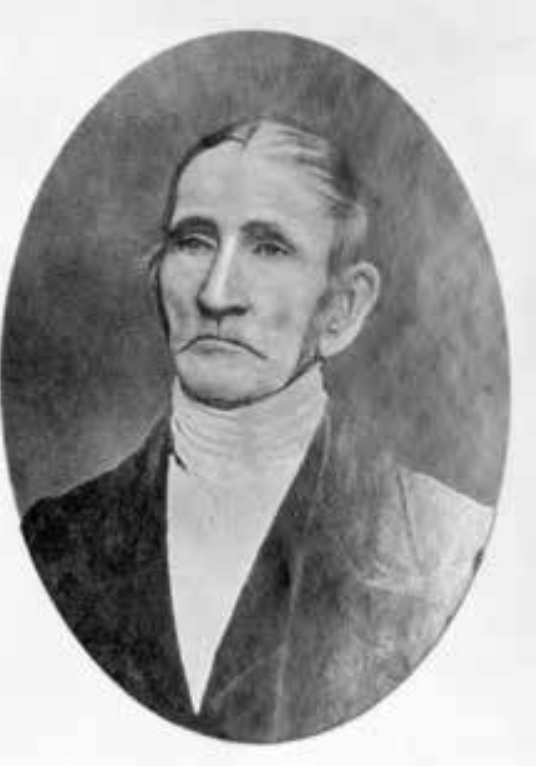

Stephen Pleasonton (WhiteHouse.gov) supposed delay in the United States adopting the Fresnel lighthouse lens. ${ }^{2}$ Specifically, these historians blame Stephen Pleasonton, the fifth auditor of the Treasury and the superintendent of the Light-House Establishment, for the department's ills. This paper seeks to correct the historiography of the Fresnel affair by showing the United States did not delay its adoption of the Fresnel lens. Manufacturing issues on the part of the French and the rate at which technology transferred in the nineteenth century demonstrate the United States' adoption of the Fresnel lens was on par with the rest of the world.

Vindication of the Treasury and Stepehn Pleasonton is not the main intent of this paper. The author, however, acknowledges the argument made herein will naturally exonerate

Pleasonton and the Treasury of any wrongdoing in bringing the Fresnel lens to the United States. Additionally, any reconsideration of Pleasonton's role in the Fresnel affair resulting from this paper should not be construed as absolving Pleasonton of any wrongdoing in other aspects of his management of the LightHouse Establishment.

\section{The Fresnel Lighthouse Lens}

Beginning in 1813, Augustin Fresnel, a French civil engineer working for the Corps des ponts et chaussées (Department of Bridges and Roads), conducted experiments on the diffraction and polarization of light. ${ }^{3}$ Through his experiments, Fresnel proved light possessed wave-like properties. His research confirmed the

2 Eric Jay Dolin, Brilliant Beacons: A History of the American Lighthouse, (New York: Liveright, 2016), 104-113; Theresa Levitt, A Short Bright Flash: Augustin Fresnel and the Birth of the Modern Lighthouse, (New York: W.W. Norton \& Company, 2013), 129-150; Wayne Wheeler, "Winslow Lewis: A Nineteenth Century Lighthouse Scalawag," Keeper's Log 21:4 (Summer 2005), 19; Ray Jones, The Lighthouse Encyclopedia: The Definitive Reference, (Guilford, CT: Globe Pequot Press, 2004), 21-5; Michael J. Rhein, Anatomy of the Lighthouse, (Glasgow, Scotland: Saraband, 2001), 148, 161; Bruce Watson, "Science Makes Better Lighthouse Lens," Smithsonian Magazine 30:5 (August 1999), 30-1; Francis Ross Holland, Jr., America's Lighthouses: An Illustrated History, (New York: Dover Publications, 1988), 16-25.

3 Diffraction is simply the bending of light. Polarization is the restriction of light waves to a single plane as they move through a particular medium, such as glass. 
earlier theories of Christiaan Huygens and Thomas Young. In 1690, Christiaan Huygens first proposed that light travelled in waves. Thomas Young expanded Huygens' theory in 1801 with his interference experiments, but he failed to prove the wave theory of light beyond doubt. With the help of Dominique François Jean Arago, Fresnel presented his research to the Académie des sciences in 1818, 1819, and 1821. In 1819, Fresnel received the Académie's grand prize in physics for his 1818 memoir on the diffraction of light.

As a result of this discovery, Fresnel created a unique dioptric optical apparatus. Rather than using parabolic reflectors to concentrate a beam of light, Fresenel used glass prisms. These were arranged in a series of vertical frames that formed a multi-slab-sided circle around the light source. Each frame created a flash of the light. The ensemble was called a bull's eye lens. It produced a brighter light that mariners could see at a much further distance. Fresnel's arrangement was more efficient because it utilized more of the available light. Reflector systems allowed more than 80 percent of the light to escape around the edges of the lens, which was only placed in front of the lamp. By comparison, Fresnel's lens captured more than 80 percent of the light. ${ }^{4}$

Fresnel believed his lens would be useful in lighting France's long coastline. He made arrangements to demonstrate the lens to the French government in 1821. The demonstration proved overwhelmingly successful and the French government authorized Fresnel to install a lens at the Tour de Cordouan lighthouse. Louis de Foix, a leading Paris architect, had designed the Tour de Cordouan lighthouse during the Renaissance era as a showcase and symbol of France's grandeur. The lighthouse even contained an apartment for the king. Located in the Bay of Biscay at the mouth of the Gironde, the light had been a guardian over a complex and potentially dangerous convergence of river and tidal currents for centuries. It is an area of heavy shipping, as Bordeaux, a major French port, is at the head of the Gironde.

Before adopting the Fresnel lens the Commission des phares, France's lighthouse authority, wanted to test the lens in a real-world application before expanding its use to other lighthouses. The difficulties manufacturing the lens delayed its installation until 1823. Over the next three years, France's leading scientific minds debated the advantages and disadvantages of this new technology. French scientists found Fresnel's optical apparatus was better than the existing system of reflectors. In 1826 after the tests, the Commission des phares adopted the lens as the standard lighting technology for all of France's lighthouses. According to a later report by the United States Navy, France upgraded all seventeen of its lighthouses within three years of the Commission des phares decision and six years of the original installation at Cordouan. ${ }^{5}$ Thus, by 1829, all of France's coastal lights contained a Fresnel lens.

4 Rhein, 164.

5 United States Navy, Report to the Secretary of the Treasury, by Lieutenants Thornton A. Jenkins and Richard Bache, $29^{\text {th }}$ Cong., $1^{\text {st }}$ sess., 1846, S. Doc. 488, 11. 
Fresnel originally classified his lenses on the basis of their size in six orders. A first order lens, the largest, measured more than six feet in diameter and stood over 100 inches tall. It weighed almost 12,800 pounds, or about six and half tons. ${ }^{6}$ It was most widely used in the tallest lighthouses and areas where mariners needed the most advanced warning of potential hazards. In comparison, a sixth order lens had a diameter of about a foot, measured seventeen inches in height, and weighed up to 220 pounds. ${ }^{7}$ Sixth order lenses were most commonly used as port markers and river lights.

Augustin Fresnel died in 1827 at the age of 39 after a long battle with tuberculosis. It is hard to say what impact Fresnel's death had on his lens. Prior to his death, Fresnel entrusted the lens manufacturing to his younger brother Léonor, who was also a civil engineer. Léonor maintained his brother's same high standards for manufacturing the lens.

\section{Treasury Oversight of the Light-House Establishment}

When Congress passed its ninth act of legislation on 7 August 1789, the federal government assumed responsibility for all of the nation's lighthouses, beacons, buoys, and public piers. ${ }^{8}$ Maritime commerce was the lifeblood of the young nation's economy and the republic's primary source of revenue. As the newly formed government was small, Congress delegated the responsibility for lighthouses to the Treasury Department. (The Bureau of Internal Revenue, the predecessor to the Internal Revenue Service, was not established until 1862 when President Lincoln enacted an income tax to pay for the Civil War. ${ }^{9}$ The Commerce Department was not established until 1903 when President Theodore Roosevelt established the Department of Commerce and Labor to deal with corporate monopolies and abuses. ${ }^{10}$ )

In the Light-House Establishment's earliest years, the secretary of the Treasury personally oversaw the service's work. For example, in 1789 Alexander Hamilton contracted with John McComb to construct a lighthouse at the mouth of the Chesapeake Bay. Hamilton also issued a contract for the completion of the Portland Head light at Cape Elizabeth, Massachusetts (now Maine), that was started by the state that same year. ${ }^{11}$ Additionally, the Treasury Department contracted for

6 "Fresnel Lens Orders, Sizes, Weights, Quantities, and Costs," United States Lighthouse Society, https://uslhs .org/fresnel-lens-orders-sizes-weights-quantities-and-costs accessed January 9, 2019.

7 Ibid.

8 United States Congress, An Act to Provide for the Establishment and Support of Lighthouses, Beacons, Buoys, and Public Piers, 1st Cong., 1st sess., ch. 9, sec. I, 1789.

9 Internal Revenue Service, "Brief History of the IRS," https:/www.irs.gov/about-irs/briefhistory-of-irs accessed 5 January 2018.

10 Jonathan Grossman, "The Origin of the U.S. Department of Labor," United States Department of Labor, https:/www.dol.gov/oasam/programs/history/dolorigabridge.htm accessed 5 January 2018.

11 Kraig Anderson, "Cape Henry (Old) Lighthouse" http://lighthousefriends.com/light.asp?ID=448 accessed 5 January 2018; Kraig Anderson, "Portland Head Lighthouse," http://lighthousefriends. com/light.asp?ID=546 accessed 5 January 2018. 


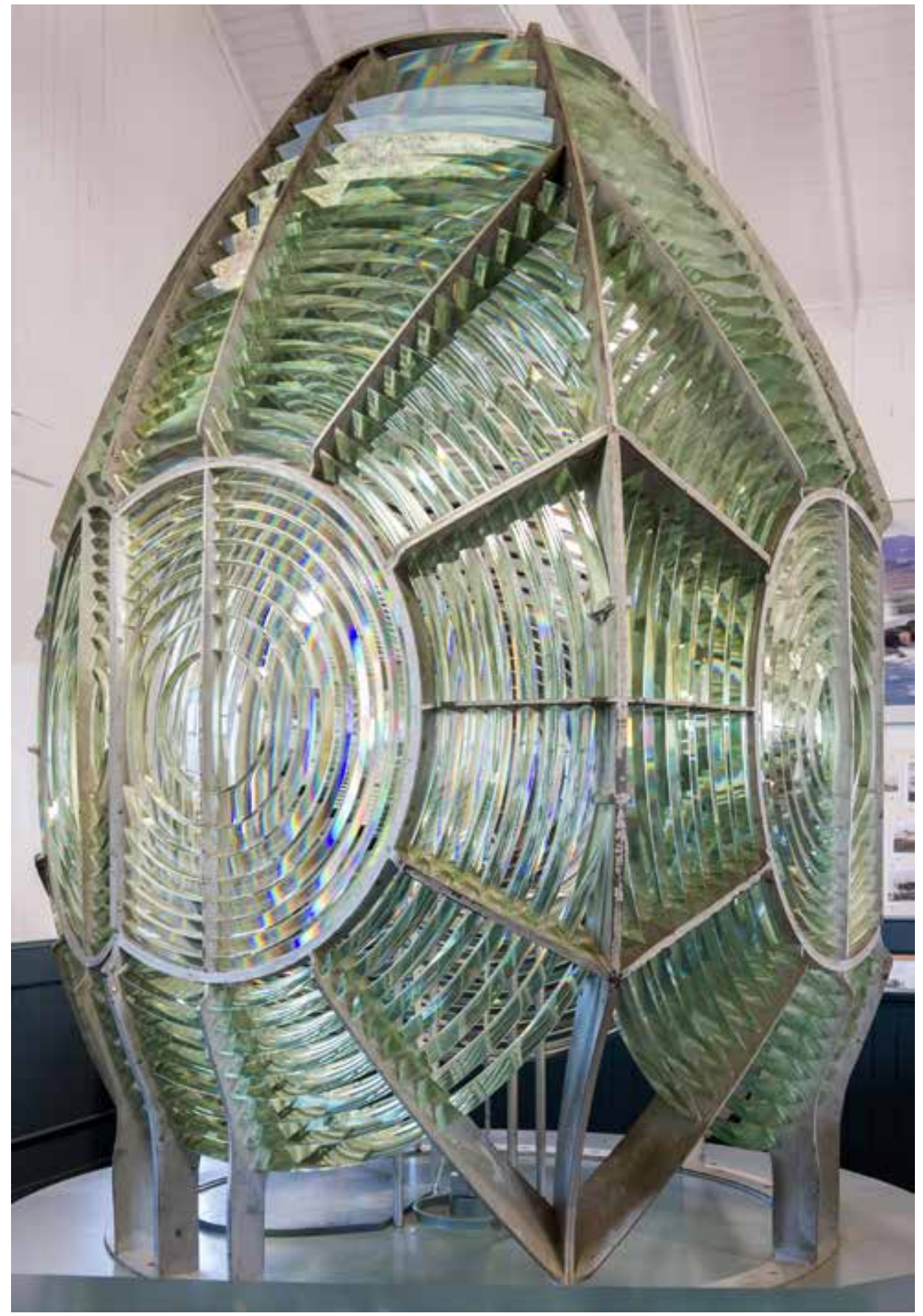

First order Fresnel Lens (wikimedia.org) 
maintenance and supplies. In 1812, Albert Gallatin received Congressional approval to purchase Winslow Lewis's patented lamp and reflector system. ${ }^{12}$ Lewis would become a fixture of the Light-house Establishment.

Initally Lewis was to "fit up" all existing lighthouses and any newly constructed beacons with his Argand-style oil lamp. He was required to maintain his lamps and reflectors for a period of seven years. Gallatin later contracted with Lewis to deliver the spermaceti oil the government purchased from Massachusetts whalers for lighting the coastal aids to navigation as Lewis was already visiting each lighthouse regularly to inspect his system and keep it in good order. The LightHouse Establishment continued his contract over the three decades as the number of lighthouses along the coast expanded from fifty-four to more than $325 .^{13}$

Thomas Jefferson initially appointed Stephen Pleasonton to federal office in 1800 as a political spoil. Delaware, Pleasonton's home state, delivered the state's presidential electors for Jefferson and the Democratic-Republicans that year. ${ }^{14}$ For the next seventeen years, Pleasonton faithfully served the State Department as a low-level clerk under Secretaries of State James Madison and James Monroe. When Monroe was elected president in 1816 he promoted Pleasonton to the newly created office of the fifth auditor of the Treasury. The promotion was a token of Monroe's gratitude for Pleasonton's unselfish actions during the War of 1812. When the British burned Washington, Pleasonton heroically saved important state documents including the Declaration of Independence, the Articles of Confederation, and Washington's commission as commander of the Continental Army. In true Jeffersonian fashion, Pleasonton modestly downplayed his role in saving the documents as simply doing his civic duty. In December 1819, a reorganization of the Treasury placed Pleasonton and the office of the fifth auditor in charge of the nation's lighthouses, beacons, buoys, and public piers. ${ }^{15}$

Pleasonton's tenure as the fifth auditor of the Treasury and superintendent of the Light-House Establishment lasted more than three decades. He served nine different presidents and fourteen secretaries of the Treasury, and oversaw the

12 United States Treasury Department, "Contract with Winslow Lewis for Lighting the Lighthouse Service in the United States, 26 March 1812 revised 9 March 1813, Conveying Winslow Lewis Patent to the United States," National Archives and Records Administration, Washington, DC, (NARA), RG 26, Entry 17E, Box 1.

13 Stephen Pleasonton to Thomas Corwin, 8 March 1852 in United States Treasury Department, Light-Houses: Letter From the Secretary of the Treasury Transmitting a Communication from the Fifth Auditor of the Treasury Respecting the Light-House System of the United States, in Reply to a Report Made to Congress by the Light-House Board, by Thomas Corwin, 32nd Cong., 1st sess., 1852, H. Doc. 88, 6-7, (United States Treasury Department, Light-Houses). Holland, Jr., 32. Arnold Burges Johnson, The Modern Lighthouse Service, (Washington, 1889), 14.

14 It is unknown what role Pleasonton may have played in Jefferson's election. Pleasonton, however, was a great nephew of Caesar Rodney. As a representative from Delaware, Caesar Rodney was a signatory to the Declaration of Independence. Caesar Rodney did not marry and had no known children.

15 Stephen Pleasonton to Winslow Lewis, 26 January 1820, NARA, RG 26, Entry 18, Volume 5,234 . 
expansion of the Light-House Establishment from fifty-four coastal beacons in 1820 to 330 lighthouses and forty-one lightships in $1852 .{ }^{16}$ Pleasonton managed this growth with prudence and fiscal responsibility. He grounded his leadership in the Jeffersonian republican values that dominated the political economy of that time.

Complaints against Pleasonton began in 1837 when Edmund Blunt, assistant superintendent of the coast survey, and Lieutenant Isaiah William Penn (better known as I. W. P.) Lewis of the Army Corps of Topographical Engineers, launched a campaign to have the military take over responsibility for the Light-House Establishment. ${ }^{17}$ Blunt and his brother George ran a nautical supply store in New York City and published the American Coast Pilot to aid mariners in navigating coastal waters. They also invented an oil lamp and reflector system which they hoped would gain favour with the Light-House Establishment. I.W.P. Lewis was the nephew of lighthouse contractor Winslow Lewis. Congress commissioned the lieutenant to inspect the nation's lighthouses in Massachusetts and Maine, for which the Blunt brothers provided Lewis with the necessary scientific equipment and supplies.

Blunt and Lieutenant Lewis complained that the Light-House Establishment was mismanaged because Pleasonton lacked the scientific knowledge needed to oversee such an enterprise. As evidence, they compared Winslow Lewis's lamp and reflector system with the Fresnel lighthouse lens that had been demonstrated in France two years after Pleasonton took office. In championing the Fresnel lens, Blunt and Lieutenant Lewis argued that Winslow Lewis's lamp and reflector system was poorly designed and provided inadequate lighting. Interestingly, a few years before Blunt and Lieutenant Lewis's complaints began, Congress removed the coast survey from the navy's responsibility. They reappointed Ferdinand Rudolph Hassler as the superintendent of the survey making it an independent agency once again. The timing of the complaints with the reassignment of the coast survey to civilian management indicate the possibility of an agenda behind the complaints. Blunt and Lewis may have wanted responsibility for the Light-House Establishment to replace the navy's loss of the coast survey. This would have given Blunt an easier path to introducing his lamp into the Light-House Establishment. ${ }^{18}$

Congress gave the Army Corps of Engineers more responsibility in surveying lighthouse sites beginning in 1838. By the 1840s, the Army Corps of Engineers began constructing lighthouses for the establishment. Pleasonton's tenure as

16 Pleasonton to Corwin, 8 March 1852.

17 The Army Corps of Topographical Engineers, sometimes referred to as the Bureau of Topographical Engineers or the US Topographical Engineers, was a distinct unit of officers responsible for designing and surveying civil works projects within the federal government. It was established in the 1830s and merged with the Army Corps of Engineers during the American Civil War.

18 Lt. I.W.P. Lewis also invented an improved oil lamp for use in the establishment. Pleasonton considered the lamp, but Lewis withdrew his design and request before any decision was made on the issue. Stephen Pleasonton to I.W.P. Lewis, November 13, 1838, NARA, RG 26, Entry 18, Volume 14, 31-2; Stephen Pleasonton to Winslow Lewis, February 13, 1839. ibid., 172-3. 
superintendent of the establishment officially ended in 1851 with the creation of the six-member board consisting of the nation's leading scientific minds. Members included Superintendent of the Coast Survey Professor Alexander Dallas Bache, Secretary of the Smithsonian Institute Joseph Henry, Captain William F. Shubrick and Commander Samuel F. Du Pont of the United States Navy, General Joseph G. Totten, chief engineer of the United States and Lieutenant James Kearney of the Army Corps of Topographical Engineers. ${ }^{19}$ With the creation of the Lighthouse Board, the Treasury Department remained responsible for administering Congressional appropriations for coastal navigation, but Pleasonton was removed from decisions regarding contracts for constructing, maintaining, or supplying the beacons.

\section{Nineteenth-Century Manufacturing and Technology Transfer}

The adoption of the Fresnel lens around the world was not as immediate as some historians have made it seem. ${ }^{20}$ The precision with which the lens had to be crafted and the problems associated with glass manufacturing in the early nineteenth century meant production was slow. The United States Treasury Department had no control over the manufacture and dissemination of the French-made Fresnel lens.

When Fresnel exhibited his lens to the French royal court in 1821 , there was only one glass manufacturer in France that could supply him with the high quality glass he needed to assemble the lens. That manufacturer was François Soleil, an eyeglass maker. Although other firms attempted to produce Fresnel's lens, none did so seriously until 1838. ${ }^{21}$ Engineering historian Julia Elton notes François Soleil "was the only serious manufacturer" of the optical apparatus and held a

19 Francis Ross Holland, Jr. claims the board was made up of nine-members. He includes two junior military officers who served as secretaries to the Board, and Robert Walker, the Treasury Secretary. The law establishing the Light-House Board only authorized four senior military officers, one junior officer to act as a secretary, and appropriate civil scientific officers. This paper assumes the junior officers acted as a recording secretaries with no authority for any actions of the board. The board was under the jurisdiction of the Treasury Department, but the Treasury secretary does not appear to have more than a working relationship with the board.

20 Holland, 18; Rhein, 161. Holland implies other countries adopted the Fresnel lens "quickly," when in fact the Dutch were the only ones outside of France to install a Fresnel lens prior to 1830. Rhein claims lighthouse authorities in England and Scotland "rapidly placed orders" for Fresnel lenses. This is incorrect. Great Britain's first Fresnel lens was not installed until 1835, more than a decade after Fresnel's original demonstration at the Tour de Cordouan lighthouse. Cited works by Eric Jay Dolin and Theresa Levitt paint a more accurate picture. Dolan notes that "By the mid1830s there were an increasing number of French lighthouse with Fresnel lenses, and other countries, among them the Netherlands and Great Britain, were also slowly making the switch to this newer, improved form of illumination" Dolan, 101. Theresa Levitt writes, "By the middle of the nineteenth century, the Fresnel lens had transformed not only the coasts of Europe, but those of Africa, Asia, and the Americas as well. Cuba, Brazil, the Bahamas, even tiny Tobago had lighthouses with dioptric lenses" Levitt, 127.

21 Levitt, 106; Thomas A. Tag, "The Henry-Lepaute Clock and Lens Works: Producers of the Fresnel Lens, Part III,” Keeper's Log 22:1 (Autumn 2005), 21. 
"virtual monopoly" on manufacturing the lens until $1850 . .^{22}$

Despite his vast experience manufacturing small optical lenses, Soleil encountered numerous problems producing the larger lighthouse lens. In 1822, Fresnel wrote to Monsieur Tassaert, the director of Soleil's glass factory at Saint Gobain, "It will not be bad if you send us another tray, because one of the first pieces was found to have a defect." Fresnel suggested the factory cast "one or two additional pieces of every type," for just such cases. ${ }^{23}$ Three years later in 1825, Fresnel continued to complain to Monsieur Tassaert about the quality of the glass stating, "I noticed at his place [Monsieur Soleil's] a large number of glass pieces that cannot serve, although they contain good enough material, because they were poorly cast." ${ }^{24}$

In the beginning, Soleil obtained his glass from Choisy-le-Roi and Saint Gobain. ${ }^{25}$ Both of these factories produced crown glass, an optical quality material with a low refractive index. Choisy-le-Roi's and Saint Gabian's production furnaces were fuelled by wood ${ }^{26}$ Wood cannot produce the high temperatures needed to make high quality optical glass. As a result, the glass was uneven or contained bubbles and streaks. This was not as much a problem for Soleil's small optical instrument lenses. Soleil could cut them from a good section of glass. A Fresnel's lens, however, used individual prisms that were much larger, manufactured in pieces to reduce the cost. ${ }^{27}$ To remove the imperfections from these larger pieces, Soleil's workers had to reheat the glass and grind it down. For the prisms forming the bull's-eye lens, Soleil's gaffers (a term used for glassblowers ${ }^{28}$ ) had to reheat the glass and then shape it in cast iron triangular shape moulds. Once moulded, the prisms were then ground and polished to ensure proper diffraction of the light. This process was very expensive, time-consuming, and labour intensive. Skilled gaffers were hard to find. Women were often employed for the final polishing. ${ }^{29}$

Once Soleil had the individual pieces of glass ready, he had to assemble them into the lens. For this Soleil used bronze rings to attach the panes of the glass bull's-eye

22 Julia Elton, "A Light to Lighten our Darkness: Lighthouse Optics and the Later Development of Fresnel's Revolutionary Refracting Lens 1780-1900," International Journal for the History of Engineering and Technology, 79:2 (July 2009), 194.

23 Augustin Fresnel to Monsieur Tassaert, 21 April 1822 in Thomas A. Tag, "The Early Development of the Fresnel Lens, Part 1," Keeper's Log 21: 3 (Spring 2005), 21.

24 Ibid., 22.

25 Ibid., 23.

26 According to J.R. Harris, an historian of the Industrial Revolution in Britain, France's glassmaking industry used wood to fuel its furnaces until 1850. J. R. Harris, Industrial Espionage and Technology Transfer: Britain and France in the Eighteenth Century, (Surrey, UK, 1998), 353.

27 Thomas A. Tag, "The Jewel in the Sand - Manufacturing Lighthouses Lenses," Keeper's Log 16:3 (Spring 2000), 23.

28 Redwood Fisher, "Manufacture of Glass in the United States," Fishers National Magazine and Industrial Record, 2:10, (March 1846), 930-1; Apsley Pellat, Curiosities of Glass Making with Details of the Processes and Productions of Ancient and Modern Ornamental Glass Manufacture, (London: David Bogue, 1849), 89-90; Dictionary of Glass-Making, (Amsterdam: Elsevier, 1983), 79.

29 Thomas A. Tag, "The Early Development of the Fresnel Lens, Part 1," Keeper's Log 21:3 (Spring 2005), 23. 
together and to hold the prisms in place. Initially, Soleil used fish glue, an adhesive extracted from boiling the skin and bones of fish, to bind the metal rings to the glass..$^{30}$ Although fish glue has a long history of use in artwork, cosmetics, and pharmacology, Soleil undoubtedly understood the marine environment of the lens and valued the adhesive's moisture-proof qualities. ${ }^{31}$ Later Soleil used litharge, a putty-like composite of calcium carbonate, lead oxide, and linseed oil.

Although the assembly may appear a routine task, the prisms' precise placement is extremely important to achieve the maximum the diffraction of the light, concentrating it into a brighter beam. According to Thomas Tag, the United States Lighthouse Society's historian of technology, "each prism was hand checked by observing the reflection of a small red ball placed in the lens focus, and then hand twisting the prism within its frame until the ball reached maximum magnification when observed from a distance." ${ }^{2}$ Given a Fresnel lens could contain as many as 1,200 prisms, this task was equally time-consuming and labour intensive.

These problems meant Soleil took two years to manufacture the first Fresnel lens for actual use. Throughout the early 1820s, Fresnel and Soleil produced an average of two to three lenses per year. ${ }^{33}$ Elton notes France built "112 new lens lights" between 1825 and 1846. Elton's figures mean Soleil was manufacturing just over five lenses per year. ${ }^{34}$ Undoubtedly, production increased over time with Soleil producing more lenses in the latter years than the earlier ones, but these figures remain consistent with the time it took the French to manufacture the United States' first experimental lenses. Additionally, these production estimates are consistent with the complexity of the Fresnel lens and the problems of manufacturing highquality glass. Although the glass could be produced in a factory, the lens itself was a highly scientific and artisan object that had to be hand assembled.

In 1829, the year France completed the conversion of its lighthouses to the Fresnel lens, the United States Treasury Department inquired about the lens through Isaac Cox Barnet, the American consul in Paris. According to a report by the United States Light-House Board, Barnet advised the Treasury to wait because Fresnel's lens "was then yet considered an experiment in France." ${ }^{35}$ As a diplomat,

30 Ibid.; Tatyana Petukhova, "A History of Fish Glue as an Artist's Material: Applications in Paper and Parchment Artifacts," The Book and Paper Group Annual, 19, (Fall 2000), 19, The American Institute for Conservation http://cool.conservation-us.org.pallas2.tcl.sc.edu/coolaic/sg/bpg/annual/ v19/bp19-29.html accessed 17 May 2019.

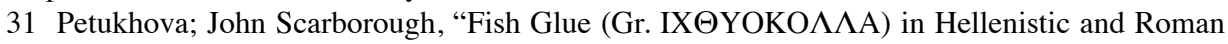
Medicine and Pharmacology," Classical Philology 110 (2015), 54.

32 Thomas A. Tag, "The Jewel in the Sand - Manufacturing Lighthouses Lenses," 23.

33 This estimate takes into consideration that Soleil continued manufacturing lighthouses lenses while the Commission des phares debated the Fresnel lens' merits. Those lenses were used by Fresnel for experiments, but were later installed in lighthouses after the Commission des phares universally adopted the lens.

34 Elton, 194.

35 United States Light-House Board Establishment, "Progress of Improvement in American Lights," in United States Light-House Board Establishment, Compilation of Public Documents and Extracts from Reports and Papers Relating to Light-Houses, Light-Vessels, and Illuminating 
it is unclear how much knowledge Barnet had of the lenticular apparatus but his reply was obviously wrong.

One might ask why the Treasury Department did not commission a domestic glassmaker to manufacture an American Fresnel lens. Although American glassmaking can be traced to the Jamestown colony, the industry remained in its infancy until the mid-1820s when pressed glass was invented..$^{36}$ American glass manufacturers fired their furnaces with wood just as the French did. ${ }^{37}$ The resulting glass was too thick and full of imperfections for Fresnel's lens and most of the glassmakers in the United States did not have the resources to reheat the glass and grind it down like Soleil. American glass also had a green tint due to the sodium and iron oxides in the soda lime available in this country. This green tint made American glass unfit for Fresnel lenses. ${ }^{38}$

\section{International Adoption of the Fresnel Lens}

There is some debate over the first non-French installation of a Fresnel lens. Levitt argues Norway was the first foreign country to use the Fresnel lens when they installed one on the island of Oks $\varnothing$ y in 1832 , followed by the Dutch installation of a second order lens at Goedereede in $1834 .{ }^{39}$ Elton, however, claims the Dutch were first when they adopted the lenticular apparatus at Oostvoorne in the mid$1820 \mathrm{~s} .^{40}$ Given Soleil's problems of manufacturing the lens and the French priority of lighting their own coast first, Levitt's claim of Norway being the first in 1832 is more reasonably accurate.

Great Britain followed a similar, but lengthier process as the French. Britain first learned of the lens in 1825 and began their own debates on the merits of Fresnel's lens. These debates were undertaken by the Royal Navy, the Northern Lighthouse Board of Scotland, Sir David Brewster, one of Britain's leading scientists, Alan Stevenson, one of Britain's premier engineers, and several professors from Cambridge University. Similar to the debate in the United States, the British assessment of Fresnel's lens was not unanimous. Stevenson, the Cambridge professors, and the navy all supported the adoption of French apparatus. Brewster, however, believed the quality of the French glass was inferior to that of Britain..$^{41}$ Like American

Apparatus, and to Beacons, Buoys, and Fog Signals, 1789 to 1871, (Washington: Government Printing Office, 1871), 324. (USLHBE, Compilation of Public Documents).

36 Kenneth M. Wilson, American Glass, 1760 - 1930, Vol. I, (New York: Hudson Hills Press, 1994), 162, 265.

37 Jane Shadel Spillman, American and European Pressed Glass in the Corning Museum of Glass, (Corning, NY: Corning Museum of Glass, 1981), 19.

38 J. R. Harris, "Saint Gobain and Ravenhead," (unpublished manuscript, 1975), 7-10, Rakow Research Library, Museum of Glass, Corning, NY; Thomas A. Tag, "The Early Development of the Fresnel Lens, Part 1," Keeper's Log 21:3 (Spring 2005), 23.

39 Levitt, 103.

40 Elton, 199.

41 “Some Account of the Northern Light-Houses," Edinburgh New Philosophical Journal, (July 1833), 17. 
glass, French glass had a similar slightly green tint. It was lighter than that found in American glass, but substandard when compared to the transparency of British glass. Brewster did not take issue with the science behind Fresnel's lens. He had, in fact, proposed the need for a similar lens in $1811 .^{42}$ Brewster recommended having a London optician manufacture Fresnel style lenses, to which the Northern Lighthouse Board of Scotland acquiesced. These were used in the British tests. Based on this initial assessment, the government commissioned the Cookson Glass Company to manufacture a British version of the Fresnel lens. When Cookson completed the lens in 1833, the Northern Lighthouse Board of Scotland conducted additional experiments. Finally, in 1835 after a decade of testing, Britain installed the Cookson lens at Inchkeith in Scotland. This was fourteen years after Fresnel's invention and only three years before the United States procured the experimental lenses for Sandy Hook and Navesink. ${ }^{43}$ A second British-made Fresnel was installed at Start Point light in England in 1836.

In 1838, Spain ordered its first lens from Léonor Fresnel. Léonor petitioned the French government for Henry Lepaute, a clockworks manufacturer, to begin manufacturing Fresnel lenses in hopes of speeding up production. The government acceded his request and granted Lepaute the right to manufacture the lens. Lepaute had worked extensively with Soleil in fitting up French lighthouses as revolving lights prior to Léonor's petition. ${ }^{44}$ When the crown granted Lepaute rights to manufacture Fresnel's lens, Léonor gave Spain's order to the clockworks manufacturer. Unhappy with losing his virtual monopoly on the lens, Soleil refused to share manufacturing information with Lepaute. As a result Lepaute experienced many of the same manufacturing issues as Soleil.

\section{Adoption of the Fresnel Lens in the United States}

The United States ordered its first two experimental Fresnel lenses in 1838. Once Congress authorized the purchase of two Fresnel lenses for testing in the United States, Pleasonton did everything in his power to expedite purchase, importation, and installation of the lenses. For instance, when the Treasury commissioned Captain Matthew C. Perry of the United States Navy to procure the lenses, Pleasonton wrote that he hoped Perry would be able to purchase two lenses already manufactured for the French government in order to speed the process. The lenses, also made by Lepaute, arrived late in 1840 but the installation ws not completed

42 Thomas Drummond, "On the Illumination of Light-Houses," Philosophical Transactions of the Royal Society of London, 120 (1830), 386-7.

43 J. Kenward, "A Review of Lighthouse Work and Economy in the United Kingdom for the Past Fifty Years,” Nature 36 (23 June 1887), 179.

44 The phrase "fitting up" is used here as it it was the most common phrase used in historical documents. It simply refers to the installation of the lamps and lenses. To fit up a lighthouse as a revolving light a clockworks mechanism was installed that rotated the lens so the light would appear to flash rather than present a constant light. 
until early 1841, the same year Italy installed its first Fresnel at Nisida in Naples. ${ }^{45}$

One of the reasons Lepaute's mechanic could not complete the installation in 1840 was because the Fresnel lens was not compatible with American lighthouses. This, again, was out of the Treasury Department's control. Pleasonton intended for the lenses to be installed at Sandy Hook in New Jersey and White Island in New Hampshire. He selected Sandy Hook because of the beacon's importance to New York shipping interests and White Island because of its proximity to the entrance of the Piscataqua River and the Portsmouth Naval Shipyard. Sandy Hook was to receive the stationary lens, while White Island would exhibit the revolving optical. Soon after the Fresnel lenses arrived in the United States, however, it was discovered that Sandy Hook and White Island were ill suited for the dioptric lighting system. At Sandy Hook, the lantern room was too small to accommodate the French lens. Pleasonton anticipated this, noting "Among the apparatus in your possession is a lantern calculated for the lenses, but whether it can be put on the tower of the Sandy Hook light cannot be determined until Mr. Lepaute's man arrives. If it will not suit, it will be an easy matter to have another one made." ${ }^{46}$ The tower at White Island was deemed too short for the intended experiments. It was then decided that both lenses would be installed in the twin towers of the Navesink Lighthouse in the New Jersey Highlands overlooking the Atlantic Ocean above Sandy Hook. ${ }^{47}$

Once Bernard completed the installation of the lenses, America's most prominent men of science began conducting experiments. These included Professors Benjamin Pierce and Joseph Lovering of Harvard University, members of the Franklin Institute, the Light-House Establishment authorities, and military officers who would later comprise the United States Light-House Board. ${ }^{48}$ These individuals began by conferring with European scientists and engineers. American scientists also collected reports of the European experiments and domestic documents relating to the debate over the quality of American lights.

Just as the British had performed comparative tests between the Fresnel lens and alternatives, so Pleasonton invited several lamp makers to participate in experiments; only two accepted the invitation. ${ }^{49}$ The first was Winslow Lewis of Boston. Lewis had made minor improvements to his lamp and reflector system,

45 Jeff Matthews, "On This Side of the Lighthouse: Development of Lighthouses in and Near Naples," Naples: Life, Death \& Miracles (October 2011) http://www.naplesldm.com/lighthouse.php accessed 29 January 2018.

46 Pleasonton to Hoyt, 18 March 1840, NARA, RG 26, Entry 18, Volume 16, 336,.

47 The term "above" here refers to Navesink being physically being higher than Sandy Hook due to its position in the highlands versus Sandy Hook's position near sea level. It does not refer to the Navesink's location on a map, which would be "below" Sandy Hook to mariners because it is south of Sandy Hook.

48 Franklin Institute, Report of the Franklin Institute on the Dioptric System of Augustin Fresnel for the Illumination of Lighthouses, (Philadelphia: Grattan \& McLean, 1850).

49 Stephen Pleasonton to Levi Woodbury, 12 November 1838, NARA, RG 26, Entry 18, Volume $14,29$. 
but for the most part it remained unchanged from when it was first introduced into American lighthouses. He submitted his system for the comparative experiments with the intent of keeping his contract. Lewis believed his system was more economical than, and therefore superior to, Fresnel's lens because his lights burned spermaceti oil, which was cheaper than the carcel oil used by the Commission des phares in France, the Northern Lighthouse Board in Scotland, and Trinity House in England.

Edmund Blunt of New York also accepted Pleasonton's invitation. He was the chief complainant of the quality of the nation's lighthouses. Blunt's lamp burned carcel oil, which was made from vegetables and expensive to manufacture. Because of the expense and the low return on investment, American farmers were reluctant to produce carcel oil. According to Pleasonton, carcel oil also spoiled more rapidly than spermaceti oil. Carcel oil had to be distributed to the lighthouses four times a year instead of once annually. Given the need to import carcel oil and distribute it more often, it's price was seen as a liability.

In September 1841, Pleasonton made a special trip to the Navesink Twin Lights to examine the Fresnel lens..$^{50}$ At Navesink, Pleasonton witnessed both a first and second order lens in operation. He was quite impressed with what he discovered. He later relayed his experience to John P. Kennedy, Chairman of the House Committee on Commerce, stating, "the cost of these lenses, however, is nothing compared to the beauty and excellence of the light they afford. They appear to be the perfection of apparatus for light-house purposes, having in view only the superiority of the light, which is reported by the pilots to be seen in clear weather a distance of forty miles." 51 Pleasonton went on to acknowledge the light from Fresnel's lens "is unquestionably better." 52

Historians of the Light-House Establishment claim Pleasonton's excitement resulted from a momentary lapse of his usual tight-fisted reserve..$^{53}$ They point to a statement Pleasonton made later in that same letter as proof that he quickly returned to his objections over the Fresnel lens. Pleasonton claimed there were drawbacks to the management of the lenses and "if the keeper be not an intelligent mechanic, and capable at all times of making the necessary repairs," it would be "unfit for use in the United States upon a large scale." ${ }^{44}$ It is true that Pleasonton opposed the introduction of the Fresnel lens. He admitted as much in his congressional testimony in $1852 .{ }^{55}$

It would be wrong however, to dismiss Pleasonton's concerns over the complexity of the Fresnel lens as unrealistic. Given the state of science in the United States

50 Stephen Pleasonton to Winslow Lewis, 20 September 1841, NARA, RG 26, Entry 18, Volume $17,97$.

51 Pleasonton to Kennedy, 28 December 1841, New Jersey Lighthouse Society, http://www.njlhs. org/njlight/firstfre.htm (accessed 5 April 2013).

52 Ibid.

53 Holland, 33; Dolin, 110.

54 Pleasonton to Kennedy, 28 December 1841.

55 Pleasonton to Corwin, 8 March 1852. 
in 1841, Pleasonton's point regarding the competency of the lighthouse keepers is justified. As Levitt notes, a decade after Bernard installed the Fresnel lens at Navesink, the Light-House Board found the first order revolving light so "out of alignment," that the second order fixed lens shone brighter. Levitt says this could only result from the "poor arrangement of the prisms." ${ }^{56}$ As stated earlier, because of the precision required in assembling the lens, it was unknown whether or not any of the formally trained engineers were capable of setting up the lens, let alone a lighthouse keeper who had little to no mechanical training. There are several instances in the Light-House Establishment's records where the keepers were not even mechanically inclined enough to maintain Winslow Lewis's simple lamp and reflector. How could they possibly be expected to maintain the more complex lens? The issue here is one of knowledge diffusion. When the lens was new in America, the science and mechanical ability required to keep the dioptric system in working order was unknown. One could argue that the lighthouse keepers in Britain and France were also retired mariners, but both countries had a greater exposure to scientific networks of exchange than did the United States. Additionally, the keepers could be trained in maintaining the lens by the very individuals who manufactured it.

\section{Pleasonton's Role and Republican Values}

As fifth auditor of the Treasury and superintendent of the Light-House Establishment, Stephen Pleasonton did not wield the enormous power over the coastal beacons with which historians have credited him. Pleasonton's position was to serve the public interest and administer Congressional appropriations. $\mathrm{He}$ was subservient to both the secretary of the Treasury and Congress. It was a role which Pleasonton understood and accepted as part of his republican belief in civic duty. As Lance Banning notes, when Congress set up the government in 1789, they "specifically charged" the Treasury Department "to report directly to Congress" and denied the Treasury Department "the right to approach Congress on [its] own initiative." ${ }^{57}$ In 1805, Albert Gallatin wrote to Benjamin Latrobe, surveyor of public buildings and architect of the ill-fated Frank's Island lighthouse at the mouth of the Mississippi River, explaining as much. According to Gallatin, "the Secretary of the Treasury has no power," except to exercise the contracts appropriated by Congress..$^{58}$ Years later when Ferdinand Rudolph Hassler, superintendent of the coast survey, recommended hiring additional assistants and increasing their salaries,

56 Levitt, 158

57 Lance Banning, The Jefferson Persuasion: Evolution of a Party Ideology, (Ithaca, NY: Cornell University Press, 1980), 123. Other departments, such as the State Department or the War Department, did not report to Congress. They reported to the President of the United States. By making the Treasury Department report directly to Congress, Congress held all the power. The Treasury was limited by Congressional appropriations and their inability to approach Congress with recommendations. They had to wait for Congress to direct them or ask for their advice.

58 Albert Gallatin to Benjamin Latrobe, 16 September 1805, NARA, RG 26, Entry 18, Volume 3. 
Levi Woodbury, reiterated former Secretary Gallatin's sentiment stating, "This Department, not having now, nor ever heretofore, any power to decide on such recommendations." ${ }^{59}$ The Treasury could not decide on such recommendations because the coast survey's budget was already appropriated by law for specific expenses. After shipmasters, mariners, and the customs collector at Boston had deemed a navy-recommended lighthouse useless, Pleasonton noted, "I had no authority to discontinue the light." ${ }^{60}$ In 1841 , Pleasonton again acknowledged his lack of authority when Captain Nicoll suggested removing a light-ship rendered useless by the installation of the experimental Fresnel lenses at Navesink Highlands Twins lights. ${ }^{61}$

Records indicate that Congress and the secretary of the Treasury granted Pleasonton a great deal of leeway in carrying out his duties, but Congressional appropriations dictated and restricted Pleasonton's actions. Congress all too often failed to provide sufficient appropriations for lighthouses, leaving the Treasury with the difficult task of making the ends meet in its administration of the establishment. For instance, in September 1819 Commissioner of Revenue Samuel H. Smith wrote to Henry A. S. Dearborn, the customs collector for the port of Boston, that the appropriations for the Long Island Head light were insufficient. The Treasury Department, however, was unable to make "any application to Congress for [the] deficiency in the appropriation." ${ }^{\prime 2}$ In 1823, Pleasonton informed Winslow Lewis that the Treasury Department could not accept the contractor's proposal for a lighthouse at Fort Gratiot because the appropriations were "but $\$ 3,500 . "{ }^{63}$

This trend of insufficient appropriations continued throughout Pleasonton's tenure as fifth auditor. In 1837, Congress authorized $\$ 3,000$ for a lighthouse at Esopus Meadows on the Hudson River, but the actual construction required twice as much. ${ }^{64}$ That same year, Congress authorized $\$ 20,000$ for a lighthouse at Carysfort Reef off the Florida Keys. Carysfort Reef, however, required two additional appropriations from Congress and ultimately cost more than $\$ 105,000$ to build ${ }^{65}$ The lighthouse at Romer Shoal in New York exceeded Congressional

59 Levi Woodbury to Ferdinand R. Hassler, 2 August 1836. NARA, RG 23, Entry 3, Box 1, 97.

60 Stephen Pleasonton to Thomas Corwin, 8 March 1952 in United States Light-House Board Establishment, Compilation of Public Documents, and Extracts from Reports and Papers Relating to Light-Houses, Light-Vessels, and Illuminating Apparatus, and to Beacons, Buoys, and Fog Signals, 1789 to 1871, (Washington, 1871), 859. Hereafter cited as USLHBE, Compilation of Public Documents.

61 Stephan Pleasonton to Jesse Hoyt, 8 March 1841,NARA, RG 26, Entry 18, Volume 16, 307. Captain Nicoll is believed to be Selick C. Nicoll, a contractor for the Light-House Establishment employed by Aymar \& Co. of New York City.

62 S. H. Smith to Henry A. S. Dearborn, 7 September 1819, NARA, RG 26, Entry 18, Volume 5, 189-203.

63 Stephen Pleasonton to Winslow Lewis, 19 December 1823, NARA, RG 26, Entry 18, Volume 6, 206.

64 Stephen Pleasonton to Levi Woodbury, 8 November 1837, in USLHBE, Compilation of Public Documents, 19.

65 Stephen Pleasonton to Winslow Lewis, 2 June 1838, NARA, RG 26, Entry 18, Volume 13, 
spending allowances by 300 percent. On 29 December 1849, Pleasonton reported to Secretary William M. Meredith that nothing could be done on the lighthouse planned for Proctorsville, Louisiana because Congress only appropriated $\$ 500 .{ }^{66}$

When Congress failed to provide sufficient funding for lighthouse construction, the appropriated funds had to be returned to the Treasury by law. The same held true in the rare instances that Congress authorized more money than necessary, as was the case in the floating light planned to be stationed off Sandy Hook, New Jersey. Congress authorized $\$ 15,000, \$ 9,000$ of which Pleasonton returned to the Treasury. ${ }^{67}$ The law did not allow Pleasonton to move the unused funds to other projects without Congressional approval. Dennis Noble has argued that Pleasonton took great pride in returning money to the Treasury. ${ }^{68} \mathrm{~A}$ more accurate assessment might be that Pleasonton was obligated to return the money and he took pride in doing his civic duty by following the letter of the law.

Congress's failure to provide sufficient funding for the Light-House Establishment meant Pleasonton did not have the authority to purchase the Fresnel lens regardless of his personal views on the subject. Pleasonton was confined by the amount of Congressional appropriations and he acknowledged as much when he expressed his willingness to purchase additional Fresnel lenses "if it be thought proper by Congress to authorize any more." ${ }^{69}$ In defending his administration, he noted, "Congress very generally makes appropriations without consulting me, and all I can do, under a clause which has been inserted in each light-house law for some years past, was to request of the secretary of the Navy to detail officers of rank to examine all doubtful sites, and report their opinions as to the expediency or otherwise of erecting buildings."70 Although Congress and the secretary of the Treasury gave Pleasonton great leeway in carrying out the duties of his job in administering the Light-House Establishment, clearly he did not have as much authority as modern historians have given him nor did he believe he had such authority.

\section{Political Economy and Republican Values}

What historians have interpreted as Pleasonton's hunger for power should be viewed as evidence of his Jeffersonian republican values. Several historians, including Lance Banning, Drew R. McCoy, and Daniel Walker Howe, have shown that Jeffersonian republican ideology dominated politics in the United

239; Rhein, 120.

66 Stephen Pleasonton to William M. Meredith, 29 December 1849, in USLHBE, Compilation of Public Documents, 537-8.

67 Pleasonton to Woodbury, 8 November 1837, in USLHBE, Compilation of Public Documents, 19.

68 Dennis L. Noble, Lighthouses \& Keepers: The United States Lighthouse Service and Its Legacy, (Annapolis, MD: Naval Institute Press, 1997), 12.

69 Stephen Pleasonton to the Honorable John P. Kennedy, 28 December 1841, New Jersey Lighthouse Society, http://www.njlhs.org/njlight/firstfre.htm (accessed 5 April 2013).

70 United States Treasury Department, Light-Houses, 5. 
States during the first half of the nineteenth century. ${ }^{71}$ This ideology focussed on prudent management and eliminating corruption in government. Treasury officials embodied these core republican values, even if they were often forced to use austere management due to insufficient Congressional appropriations. For example, when Benjamin Latrobe submitted a proposal for a lighthouse to be built at the mouth of the Mississippi River in 1805, Albert Gallatin questioned Latrobe's expertise fearing "the top of the pyramid would bend, in heavy storms." Gallatin asked Latrobe to "dispel [his] fear of the bending" before the secretary would solicit bids to construct the lighthouse "in conformity with [the] plan."72

In 1825 the Treasury Department likewise refused to pay for work on a pier in Ohio. The Grand River Harbor Company owned the promenade but intended to sell it to the federal government. Grand River hired Abraham Skinner to repair the structure. Skinner sought payment from the United States in advance of the Congressional appropriations for the purchase. Grand River sought to increase the pier's value prior to its sale. In a letter to Thomas Foster, the regional customs agent in Sandusky, Ohio, Pleasonton informed Foster that the Grand River Harbor Company "expect[ed] the United States to buy [the pier], probably at a high rate. This could not have been the intention of the law, and [the Treasury Department] cannot undertake to authorize any such measures."73

If Treasury officials were cautious and deliberate in their administration of their assigned duties, it was because they were committed to the Jeffersonian republican ideology. They believed it was their civic duty to administer their accounts with due diligence, frugality, and caution. Pleasonton exhibited these values throughout his tenure as fifth auditor. He often took a harsh tone with the LightHouse Establishment's chief contractor, Winslow Lewis, for poor workmanship. In 1822, Pleasonton reprimanded Lewis for the defective workmanship at the St. John's River and St. Mark's Island lighthouses. He forced Lewis to tear down the

71 See generally, Lance Banning, The Jefferson Persuasion: Evolution of a Party Ideology, (Ithaca: Cornell University Press 1980), Nathan O. Hatch, The Democratization of American Christianity, (New Haven: Yale University Press, 1991); Drew R. McCoy, The Elusive Republic: Political Economy in Jeffersonian America, (Chapel Hill: University of North Carolina Press 1996); Daniel Walker Howe, What Hath God Wrought? The Transformation of America, 1815-1848, (New York: Oxford University Press, 2009), 275, 404, 541; John Lauritz Larson, Internal Improvement: National Public Works and the Promise of Popular Government in the Early United States, (Chapel Hill: University of North Carolina Press, 2001), 6. For more information on the extension of republicanism beyond 1824 when the Democratic-Republican Party splintered, see Daniel T. Rogers, "Republicanism: the Career of a Concept," Journal of American History 79:1 (Jun 1992): 11-38, particularly page 30; John Lauritz Larson, The Market Revolution in America: Liberty, Ambition, and the Eclipse of the Common Good, (New York: Cambridge University Press, 2009); Mark R. Wilson, The Business of Civil War: Military Mobilization and the State, 1861-1865, (Baltimore: Johns Hopkins University Press, 2010); Maria Fanis, Secular Morality and International Security: American and British Decisions about War, (Ann Arbor, MI: University of Michigan Press, 2011), chapter 3, particularly pp. 119 - 124; Forrest A Nabors, From Oligarchy to Republicanism: The Great Task of Reconstruction, (Columbia, MO: University of Missouri Press, 2017).

72 Gallatin to Latrobe, 16 September 1805, NARA, RG 26, Entry 18, Volume 2, 328.

73 Stephen Pleasonton to Thomas Foster, 26 May 1825, NARA, RG 26, Entry 18, Volume 6, 416. 
defective structures and rebuild them at Lewis' own expense. Lighthouse historians often overlook the harsh tone Pleasonton took with Lewis and characterize their relationship as cordial. This interpretation of Pleasonton and Lewis' relationship is incorrect. It is true that Pleasonton relied heavily on Lewis and his knowledge, but their relationship was in fact a business affair based on Lewis's consistently low bids. As James F. Nagle acknowledges, government contracting with the lowest bidder became routine by the late 1790 s, even if the practice had not been codified into law. ${ }^{74}$ Lewis's bids were so low other contractors eventually stopped bidding on lighthouse contracts. At that point Pleasonton sometimes went directly to Lewis as a matter of expediency, but Pleasonton admonished Lewis as often as he praised him. ${ }^{75}$

In 1830, Lewis asked for advanced payment on a contract but Pleasonton firmly held to his republican beliefs. He informed Lewis, "although the law of January 1823, allows a discretion to make payments for work done for the United States as it progresses," he found it prudent "to lay down a rule to defer all payments until the entire work executed." Pleasonton's prudence was a check on possible corruption and fraud. He further explained, "From this rule I have made no exceptions, and I regret that my duty now, will not permit me to make an exception in your favor."76 Pleasonton exercised similar caution in 1837 when he recommended "that authority be given by law" the lighthouse at Romer Shoal "to be done by a competent engineer; it being unsafe to assign a work of such difficult execution to the lowest bidder, as is done in ordinary cases." 77

Pleasonton's values were consistent throughout the Fresnel affair. He noted, "my chief object was economy" and the American-made lamps and reflectors did "not cost more than one-sixth as much" as the French lens. ${ }^{78}$ Pleasonton saw it as his duty to maintain strict economy in his administration of the Light-House Establishment. Additionally, the Treasury Department's preference for domestically produced goods supported the republican idea of self-sufficiency.

Pleasonton felt it was his civic duty to have the lenses installed as soon as possible. When the two apparatuses arrived in New York in 1840, Pleasonton requested that Henry Lepaute, the French manufacturer, send one of his "best workmen to put these lenses in our lighthouses."79 According to the Light-House Establishment, Pleasonton made this request "to prevent any failure" of putting the lenses in operation. As the lenses were "unknown in this country," Pleasonton "believed

74 James Risk, "Lamps, Maps, Mud-Machines, and Signal Flags: Science, Technology, and Commerce in the Early United States," PhD diss., University of South Carolina, 2017, 105 n99.

75 Risk, 186 n53.

76 Stephen Pleasonton to Winslow Lewis, 27 August 1830, NARA, RG 26, Entry 18, Volume 8, 99.

77 Stephen Pleasonton to Levi Woodbury, 8 November 1837, in USLHBE, Compilation of Public Documents, 19.

78 Stephen Pleasonton to Levi Woodbury, 22 January 1838, in USLHBE, Compilation of Public Documents, 113.

79 Stephen Pleasonton to Jesse Hoyt, 18 March 1840, NARA, RG 26, Entry 18, Volume 16, 336. 
that no one here was capable of arranging them correctly." 80 Whether or not any of the Army Corps of Engineers who did work for the Light-House Establishment, such as Major Hartman Bache, Lieutenant I. W. P. Lewis, or Lieutenant George Gordon Meade, could have properly arranged the lenses is unknown. It is possible their training as engineers would have facilitated the installation of the lenses, but it also might have taken them much longer since they had no training in the optical sciences. The lenses arrived packed in ninety-four crates. ${ }^{81}$ In this case, Pleasonton's cautious approach was probably for the best.

Pleasonton urged his regional superintendent, Jesse Hoyt, to provide the French mechanic, "whatever aid he may require in the persecution of the work." 82 Lepaute sent a Monsieur Bernard to install the lenses. Because Bernard arrived late in the year, Pleasonton voiced concern that the work could not be completed before winter and recommended delaying the installation until the next year. ${ }^{83}$ Yet, after Bernard insisted that the lenses could be installed in time, Pleasonton encouraged all speed in the installation in hopes the work would be completed "before the cold weather shall set in." 84

Despite the Treasury Department's efforts to ensure an expedient installation of the lens, scholars have cited comments made by Captain Perry as evidence that Pleasonton perpetuated the supposed delay in importing the Fresnel lens. In a letter to his friend Eugene A. Vail a year after his assignment, Captain Perry complained of "General Cass communicating his determination not to comply with the request of Mr. Pleasonton in reference to the payments for the lenses manufactured by $\mathrm{Mr}$. Lepaute." Perry believed "Mr. Pleasonton has purposely thrown these difficulties in the way." 85 Pleasonton however had nothing to do with General Cass' refusal to pay Perry's bills. ${ }^{86}$ Rather, he was forced to make arrangements through the United States' bankers in England, Rothschild \& Son, to avoid embarrassment to Mr. Lepaute and the United States. ${ }^{87}$

One reason General Cass may have refused to pay Perry's bills was that Perry did not submit his bills in accordance with the agreed-upon contractual installment

80 USLHBE, Compilation of Public Documents, 325.

81 Pleasonton to Hoyt, 18 March 1840, NARA RG 26, Entry 18, Volume 16, 336,.

82 Stephen Pleasonton to Jesse Hoyt, 24 November 1840, NARA, RG 26, Entry 18, Volume 16 p. 181-2.

83 Stephen Pleasonton to the Honorable John Davis, NARA, RG 26, Entry $17 \mathrm{H}$.

84 Pleasonton to Davis, 24 November 1840,NARA, RG 26, Entry 18, Volume 16, 181-2.

85 Captain Matthew Calbraith Perry to Eugene A. Vail, New York, 15 June 1839, NARA, RG 45, Entry 464. "Office of Naval Records \& Library: Subject File U.S. Navy 1775 - 1910 KL Lighthouse and other navigational aids." General Lewis Cass was one of several dispersing agents for the United States government. A dispersing agent paid government expenses when individuals submitted receipts for initial payment or reimbursement. Cass was later appointed secretary of State by President James Buchanan.

86 John H. Schroeder, Matthew Calbraith Perry: Antebellum Sailor and Diplomat, (Annapolis: Naval Institute Press, 2001), 85. Levitt,142.

87 Stephen Pleasonton to Levi Woodbury, 17 September 1839, NARA, RG 26, Entry 18, Volume 15, 40-1. 
plan, a plan designed to prevent corruption in government transactions. As Pleasonton noted in his 27 September 1838 correspondence with Perry, "although we do not make advances for work done at home, yet, in the case of these lenses, which are made by artists employed by the French Government, you will make such advances, from time to time, as may be necessary to secure a prompt and faithful execution of the work." $" 88$ Perry, however, neglected his duty to fulfill the agreed upon arrangement. ${ }^{89}$ Perry was apparently too consumed with his naval duties in testing the new steam frigate Fulton to concern himself with properly securing the two Fresnel lenses. Perry admitted as much in a 10 April 1840 report to Congress when he claimed he was "deeply occupied with other official engagements." 90 Pleasonton admonished Perry for neglecting his duty. He wrote the young navy captain, "Had you drawn bills for the different instalments [sic], stipulated to be paid Mr. Lepaute, agreeably to the arrangement made with this Office,...every difficulty and inconvenience would have been obviated."'11

Perry's instructions were standard protocol for the Treasury Department. These procedures were put in place to eliminate the possibility of fraud in the transaction. This was especially important in dealing with foreign transactions that required the conversion of various currencies, but the elimination of fraud was a core republican value. General Cass, Pleasonton, and the rest of the Treasury officials continued to work diligently to prevent corruption in all of their transactions. The United States' purchase of the Fresnel lighthouse lens was no exception.

\section{Conclusion}

It is easy to make a scapegoat of Stephen Pleasonton and the Treasury Department for their role in introducing the Fresnel lighthouse lens into the United States Light-House Establishment. Pleasonton admitted that he was against importing the French technology on the basis of its expensive cost. Little is gained, however, from pointing fingers and placing blame; better to place the United States' adoption of the Fresnel lens in the proper historical context. To do that means understanding nineteenth-century technology transfer.

Making the Fresnel lens required very precise manufacturing technology that in turn needed specialized expert knowledge. Between Soleil guarding his secrets and the nature of international science communication, sharing knowledge was slow. When the lens was acquired by other countries, the learning curve was steep.

88 Stephen Pleasonton to Capt. Matthew C. Perry, 27 September 1838, NARA, RG 45, Entry 464, "Office of Naval Records \& Library: Subject File U.S. Navy 1775 - 1910 KL - Lighthouse and other navigational aids."

89 Perry to Vail. Stephen Pleasonton to Capt. Matthew C. Perry, 16 May 1839, NARA, RG 26, Entry 18, Volume 14, 340-1.

90 Office of the President of the United States. Communication from the President of the United States, by Martin Van Buren, $26^{\text {th }}$ Cong., ${ }^{\text {st }}$ sess., S. Doc. 619 (Washington: Government Printing Office, 1840).

91 Ibid. 
In both Britain and the United States, lighthouses had to be rebuilt in order to accommodate the Fresnel lens. Once installed, there was much that had to be done for the receiving nation to gain the requisite knowledge of the lens, including extensive testing. All of this also played an important role in the United States' adoption of the Fresnel lens.

The historical context also includes Jeffersonian republicanism that dominated the political economy in the early nineteenth century. Jeffersonian republicanism stressed the importance of civic duty, prudent and frugal fiscal management, and the elimination of corruption. Treasury officials worked diligently to administer the government according to those core republican values and Stephen Pleasonton was no exception. He held his civic duty in the highest regard as he consistently followed the letter of the law. His prudent and frugal management, however, invited scrutiny of his administration. Pleasonton's critics failed to see his civic duty or understand his prudent management as part of his republican values.

Lastly, to understand fully the United States' adoption of the Fresnel lighthouse lens, one must examine who actually had the authority to purchase the lens. Prior historians have argued that Stephen Pleasonton had that authority. As fifth auditor of the Treasury, Pleasonton oversaw the Light-House Establishment and its day-to-day management. Congressional appropriations, however, show that Congress often failed to provide sufficient funding for America's coastal beacons. Pleasonton's authority was thus limited. He had to work within the confines of what he was given. Pleasonton acknowledged the limits of his authority when he agreed to order more Fresnels if Congress authorized their purchase.

Only when the Fresnel affair is in the proper historical context can we gain greater insight into the real history of the Fresnel lighthouse lens. Then can we see that the United States' adoption of the lighthouse apparatus was not delayed, but on par with the rest of the world. 